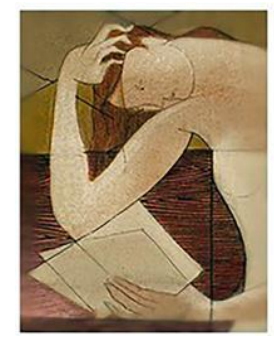

\title{
O preto no branco: memória, identidade e resistência na poesia afrobrasileira de Cuti
}

\author{
Black into the white: memory, identity and resistance in Cuti's Afro-Brazilian \\ poetry
}

\section{Cleo Amorim Nascimento ${ }^{1}$}

Resumo: A literatura pode configurar-se como um meio multifacetado de versar sobre as várias nuances de uma sociedade. No texto literário cabem memórias, identidades e uma infinidade de estórias que constroem a história de um povo e podem definir sentimentos de pertença às nações do mundo. Nesse sentido, cabe a este artigo o propósito de buscar na literatura afrobrasileira, mais precisamente na poesia de Luiz Silva, poeta afrobrasileiro conhecido com o pseudônimo de CUTI, questões referentes à poesia de autoria negra, bem como discutir a construção da memória nacional sobre a perspectiva de um negro falando sobre o escravismo a partir dos poemas "Amor" e "E pensar". Caberão ainda, neste artigo, discussões sobre a poesia de caráter de resistência nos poemas "Cheiro" e "Palavra" que suscitam questões referentes à auto-aceitação e sentimento de pertença à identidade afrobrasileira no Brasil. A importância deste artigo justifica-se por promover discussões que suscitam a revisão da história da escravidão no Brasil sobre a ótica de textos literários que nos permitem conhecer a importância da literatura afrobrasileira dentro da literatura brasileira. Cabe ainda destacar que o referencial teórico que embasará as discussões e análises tem suporte nas contribuições de Bernd (1988), Costa (1998), Duarte (2008), Santos (1964), entre outros.

Palavras-chave: Literatura afrobrasileira; poesia; memória; identidade; resistência.

Abstract: Literature can be configured as a multifaceted means of dealing with the various nuances of a society. The literary text holds memories, identities and many stories that build the history of a people and can define feelings of belonging to the world's nations. In this sense, the purpose of this article is to seek in the Afro-Brazilian literature, more precisely in Luiz Silva's poetry, an Afro-Brazilian poet known as CUTI, questions regarding black authorship poetry, as well as discussing the construction of national memory about the perspective of a black man talking about slavery from the poems "Love" and "And think". In this article, discussions about poetry of a resistance character will also be included in the poems "Smell" and "Word" that raise questions regarding self-acceptance and a sense of belonging to AfroBrazilian identity in Brazil. Therefore, the importance of this article is justified by promoting discussions that raise the review of the slaver history in Brazil from the perspective of literary texts that allow us to promote the importance of Afro-Brazilian literature within Brazilian literature. It should also be noted that the theoretical framework that will support the discussions and analyzes is based on the contributions of Bernd (1988), Costa (1998), Duarte (2008), Santos (1964), among others.

Keywords: Afro-Brazilian literature; poetry; memory; identity; resistance.

\footnotetext{
${ }^{1}$ Mestra em Letras pela Universidade Federal de Roraima. Professora EBTT do Colégio de Aplicação da Universidade Federal de Roraima (CAp/UFRR). Doutoranda em Letras na Universidade Federal do Rio Grande do Sul (UFRGS).
} 


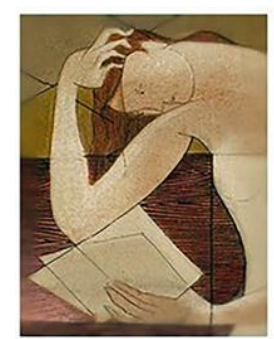

\section{1 "Negro ou afro tanto faz"2, eu existo.}

O poema em epígrafe neste artigo traz um eu lírico que afirma que sua poesia se compromete com o desnudar de sua própria história. Nela, figuram versos de um eu lírico que pulveriza seus sentimentos sobre aqueles que se sentem superiores e vitimam os negros com o seu racismo. É uma poesia que tem ritmo, é soul, é samba, é a personificação de uma gente que faz do ódio e do ressentimento uma arma para lutar contra a raça que se julga pura, mas que cede à beleza e aos encantos das raízes negras que compõem o ritmo e a cultura do Brasil.

Essa é a poesia de Luiz Silva, o Cuti, dono de um fazer poético que externa as inquietações e angústias do povo negro que se presentifica "nos tempos e espaços históricos de nossa constituição enquanto povo" (DUARTE, 2008, p. 1). Seus versos fazem memória a esse povo severamente explorado, que derramou sangue e suor nas terras brasileiras, que construiu a memória e a história deste país e, embora tenha em

\footnotetext{
${ }^{2}$ CUTI, Luiz Silva. Literatura negro-brasileira. São Paulo: Selo Negro, 2010.
} 


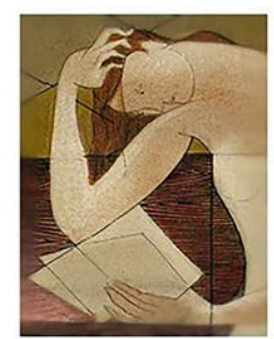

sua descendência a matiz forte da cor negra, ainda nos dias atuais convive com fortes episódios de racismo.

Cuti possui uma poesia que:

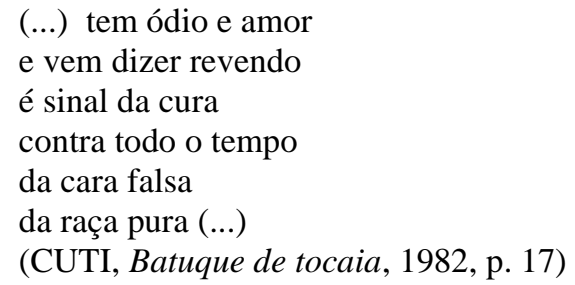

Seus versos externam uma relação de amor e ódio, que diz o não dito, contesta as descrições dos livros que contam apenas parte da nossa história e reduzem a memória nacional a uma identidade homogênea, como se fosse possível apagar os cantos, os gritos entalados na garganta, as lutas e o sangue vivo das palavras daqueles covardemente silenciados no passado e destituídos de suas identidades a custa da ilusão de uma raça pura.

\section{2 "Sou branco por dentro, sou uma formidável caveira."}

A frase anterior é um pequeno poema, da autoria de Luiz Silva, cujo título Sou Branco remete a uma série de incógnitas sobre o que significa ser branco, pois, ao contextualizar sua escrita, vemos que esse é um dos poemas escritos por um negro, afrodescendente, que, ao longo da obra Batuque de Tocaia, externa as suas angústias e posicionamentos com relação ao que significa ser negro no Brasil. O poema é ao mesmo tempo provocativo e contestativo, pois traz reflexões sobre o que pode nos distanciar em termos de cores e raças. Mostra que por dentro somos todos iguais, somos brancos, somos caveiras brancas que se igualam em sua estrutura óssea e que, ao serem analisadas a olho nu, não traduzem as diferentes identidades construídas. O que ainda nos difere são conceitos e estereótipos formados desde uma memória coletiva promulgada ao longo dos anos e que constituiu grandes discrepâncias em nome de uma suposta superioridade. 

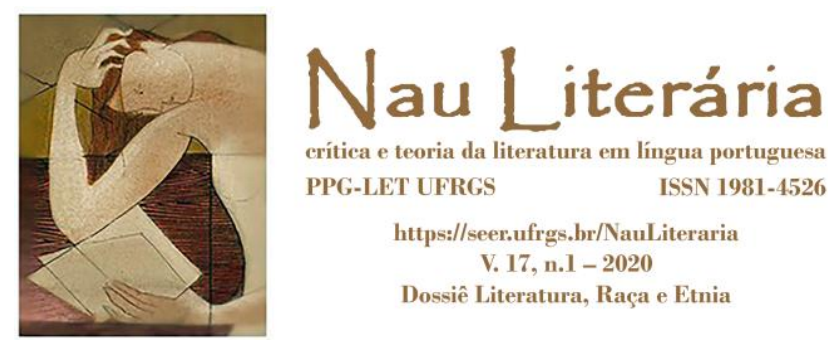

Luiz Silva, cujo pseudônimo é Cuti, é um poeta, ficcionista, dramaturgo e ensaísta, que está entre os escritores mais cultuados no Brasil por suas significativas contribuições à literatura negra contemporânea do país. Nascido em 31 de outubro de 1951, em Ourinhos (SP), Cuti é formado em Letras pela Universidade de São Paulo (USP), é mestre em Teoria da Literatura e doutor em Literatura Brasileira pelo Instituto de Estudos da Linguagem - Unicamp. É um dos fundadores dos “Cadernos Negros”, uma série de publicação anual das produções literárias (poesia e prosa) de autores afrobrasileiros de vários estados brasileiros que se mantém ativa desde a sua fundação em 1978; é também um dos fundadores e membros da ONG "Quilombhoje Literatura", nascida em 1980, e que tem por objetivo discutir e aprofundar as experiências negras na literatura (CAVALCANTE, 2017, p. 89).

Por essas questões, o escritor é considerado um militante da causa negra, ou seja, suas obras têm como fundo "questões relativas à afirmação de identidade, à crítica social e, principalmente, à valorização da imagem do negro como sujeito no contexto brasileiro." (CAVALCANTE, 2017, p. 90).

Dentre suas principais publicações relacionadas a essa temática, temos como destaque "Poemas de carapinha" (1978), "Batuque de tocaia" (1982), "Flash Crioulo" (1987), "Sanga" (2002), "Negros em contos" (1987) e "Negrosia: Antologia Poética" (2007) (CAVALCANTE, 2017, p. 90). Daremos ênfase a sua produção poética, pois sua obra tem como característica o compromisso com uma literatura que revela as vozes negras que romperam silêncios e se transformaram de lamentos e sussurros em gritos vibrantes (DUARTE, 2008, p. 7).

Neste artigo, destacaremos poemas retirados de Batuque de Tocaia. Publicado no ano de 1982, composto por 47 poemas, esse livro é descrito por Aristides Barbosa, no prefácio, como "um poemário, cujos poemas, ora são armas de luta, ora um espelho cristalino a refletir a mazelosa situação em que vive ainda a antiga mão-de-obra da economia do Brasil escravagista, agora mais do que nunca, sedenta de justiça." (BARBOSA in CUTI, 1982, p. 11). Versos que expõem a violência da escravidão, a 

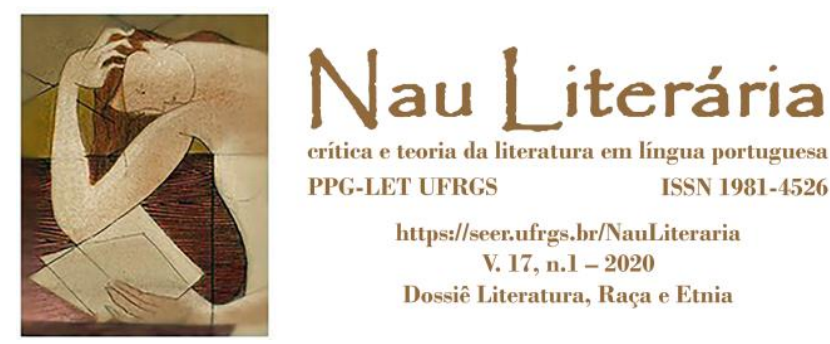

construção do País com suor, sangue e lágrimas daqueles que foram covardemente capturados e arrastados para o martírio da escravidão e que, após a abolição, ainda sofrem com o peso do racismo que persegue, humilha e mata em nome de uma falsa superioridade de raças.

O título do livro faz referência a dois termos comuns aos negros escravizados pela sociedade escravocrata, pois, ao som do batuque, os negros dançavam e lutavam nas senzalas como uma das formas de poderem se sentir vivos e ligados as suas raízes. O termo Tocaia, por sua vez, intitula ainda um dos poemas do livro. No cerne desse termo, podemos sentir a tensão sofrida pelos escravos que tentavam fugir dos seus cativeiros, bem como sentimos também a apreensão dos negros que, refugiados nos quilombos, viviam em constante vigília para que não fossem capturados novamente.

Sendo assim, a análise dos poemas eleitos para este artigo, bem como as discussões teóricas pretendem externar as tensões referentes à escravidão e à colonização do Brasil, narradas pelo ponto de vista de um afrodescendente pelo viés da literatura e, desse modo, rediscutir o que foi dito, e como foi dito, por aqueles que escreveram a nossa história. Este artigo busca também esclarecer que, num país plural e diverso como o Brasil, torna-se uma questão bastante relevante dar voz à resistência, à auto-aceitação e ao sentimento de pertencimento propostos pela literatura afrobrasileira.

\section{Rios que contam a história: colonialismo e escravidão}

Buscando referência etimológica da palavra Rios, encontramos a seguinte definição "curso de água natural que deságua noutro, no mar ou num lago: os rios correm para o mar”3. Com base nessa definição, buscamos agora elucidar as várias histórias que, como rios, percorreram os canais da história nacional e que por anos mantiveram apenas um curso, auto-intitulado memória nacional e que, a partir do século

\footnotetext{
${ }^{3}$ Rio-Dicio. Dicionário On-line de português. Disponível em: <https://www.dicio.com.br/rio/>. Acesso em 02 fev 2020.
} 

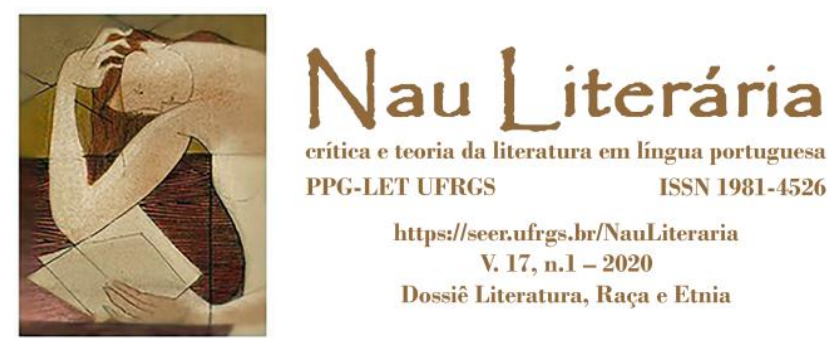

$\mathrm{XX}$ viram desaguar em si novos cursos que trouxeram o fluir de novas histórias com sentimentos, ritmos, gritos e palavras, dando à palavra negro um lugar de destaque.

Em seu ensaio Colonialidad del poder, eurocentrismo y América Latina (2000), Aníbal Quijano explica como se deu a constituição da América Latina com base no conceito de raça. Esclarece que a América se constituiu histórica e socialmente com base em uma visão eurocêntrica, ou seja, com base na ideia de raça como fator determinante para organizar sociedades divididas entre conquistadores e conquistados, sendo esses últimos classificados como inferiores social e culturalmente, o que compôs inicialmente a população da América e, mais tarde, o mundo sobre um novo padrão de poder (QUIJANO, 2000, p. 201).

Para o autor, a ideia de raça consistia na classificação das diferenças fenotípicas (aparência física) que categorizava as identidades sociais historicamente novas, como as dos índios, negros e mestiços, como inferiores. Em razão dessa ideia, essas identidades foram redefinidas como instrumentos de classificação social básico da população. De um lado, os colonizadores europeus que se auto-intitularam "brancos" e, portanto, julgavam-se a parte superior, e do outro, as raças colonizadas, negros explorados e escravizados, e os índios como mão de obra barata, intitulados raças inferiores. Tratavase, portanto, de uma distribuição racista do trabalho no interior do capitalismo colonial/moderno que se manteve durante todo o período colonial e que alcançou expansão mundial quando a raça dominante, os europeus (os brancos), a partir do século XVIII, utilizaram o mesmo critério de classificação social para toda a população mundial (QUIJANO, 2000, p. 202-204).

Desde essa perspectiva eurocêntrica, raças como negros (ou africanos) e índios foram condenadas como "inferiores" pelo fato de os sujeitos não serem considerados "racionais" e terem seu "corpo", em consequência, mais próximo à "natureza", o que os convertia em domináveis e exploráveis (QUIJANO, 2000, p. 224).

As regiões e populações dominadas foram submetidas a um processo de reidentificação histórica, pois lhes foram atribuídas novas identidades geoculturais. Aos 

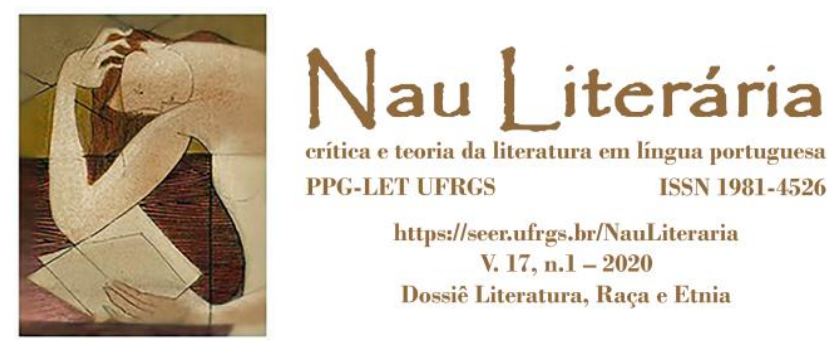

povos colonizados era imposta a obrigação de aprender parcialmente a cultura dos dominadores em tudo o que fosse necessário para reproduzir a dominação, seja no campo da atividade material, tecnológica, a subjetiva e, especialmente, a religiosa.

Na perspectiva eurocêntrica, a formação de Estados-nação foi teorizada, ou seja, imaginada como expressão de homogeneização da população em termos de experiências históricas comuns. Essa homogeneização consistia na formação de um espaço comum de identidade e de sentido para a população de um espaço dominado. Convém destacar que Quijano apresenta o conceito de Estado-nação como uma sociedade nacionalizada e, por isso, politicamente organizada, uma estrutura de poder, que se constituiu por intermédio de um processo de colonização de alguns povos sobre outros, que nesse sentido, eram povos estrangeiros, tidos como os outros, índios, negros e mestiços, considerados raças inferiores (QUIJANO, 2000, p. 226).

Os países da América Latina atraíram também milhares de imigrantes europeus, consolidando na aparência a branquitude de suas sociedades. Assim, isto também consolidou, na aparência, o processo de homogeneização nesses países que tardaram a considerarem-se com identidade nacional e cultural próprias diferentes da Europa, porque não admitiam que sua identidade pudesse ser associada à herança histórica latino-americana e, em particular, qualquer parentesco com a população indígena. "No caso do Brasil, os negros não eram senão escravos e a maioria dos índios estava constituída por povos da Amazônia, sendo desta maneira estrangeiros para o novo Estado."4. (QUIJANO, 2000, p. 233).

Cuti (1982) retrata bem esse processo de colonização e constituição do Brasil em Estado-Nação em seu poema Amor:

\section{AMOR}

Amo esta minha terra

\footnotetext{
4 "En el caso del Brasil, los negros no eran sino esclavos y la mayoría de indios estaba constituida por pueblos de la Amazonía, siendo de esta manera extranjeros para el nuevo Estado". (QUIJANO, 2000, p. 233).
} 


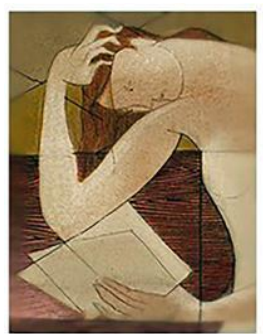

onde os ossos de meus avós gritam o grito interno dos ossos na carne do chão

e Oxumaré sobe em riso e clarão

esta terra

onde os rios contam a história de lutas quilombolas

à quem tapa os ouvidos

Amo esta terra

do café da cana do ouro

do sangue do sangue do sangue

do meu sangue

esta terra Brasil

do carnaval do futebol do anil

do suor do suor do suor

do meu suor

esta terra

em que confundem amor e prata

violência e nada

exploração e paz

esta terra

recortada por veias negras

abertas

esta terra

onde donos brancos

jogam no barranco

os sonhos do povo

esta terra

África enterrada

a custa de porrada,

viva

e que inspira

seus filhos

esta terra

coração da diáspora

onde brancos se envergonham de serem negros (...)

(CUTI, Batuque de tocaia, 1982, p. 36)

O poema destaca o sofrimento dos seus antepassados negros comercializados como mercadoria vil e a exploração atroz a qual foram submetidos. O poema "Amor" provoca um paradoxo já em seu título, pois, embora remeta a algo que parece doce e 

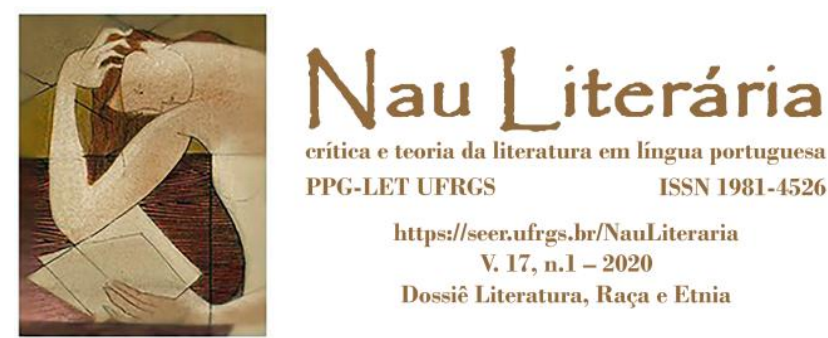

afável, revela em seus versos que a história do Brasil não foi algo tão amável, pois se constituiu de gritos, lutas e dores de um povo que foi raptado, explorado e verteu suor e sangue que escorreram por terra e fincaram suas raízes.

O eu lírico revela pelo Brasil uma relação de amor e ódio, pois, ao mesmo tempo em que o exalta por ser a "terra do carnaval do futebol", paixões nacionais, evoca na ancestralidade o sangue dos seus que fora derramado em nome da ganância, para falar de suas lutas para se libertarem dos "donos brancos", que enterravam seus sonhos, sua identidade e os anulavam enquanto pessoas. É possível ainda identificar que o eu-lírico descreve o Brasil como um lugar construído a partir da labuta dos negros no engenho, nas plantações "do café da cana" e na exploração das minas "do ouro" e demais metais preciosos, bem como faz referência à contribuição dos negros para a construção cultural de nosso país, ao falar de matizes religiosas quando cita o orixá "Oxumaré5” pertencente à Umbanda, revelando a influência da espiritualidade trazida da África pelos negros na construção de algumas religiões brasileiras.

O poema em questão nos permite a conexão entre passado, retomando o processo de colonização, bem como nos leva à conexão com o presente, pois "retomar o passado e refletir sobre ele no presente constitui uma forma de autoconhecimento e de (re)construção identitária" (CAVALCANTE, 2017, p. 95), ao passo que provoca nos "brancos [que] se envergonham de serem negros" uma reflexão sobre suas raízes e a possibilidade de se reconstruírem em termos de identidade, para que não haja nenhum tipo de preconceito de raça ou anulação do orgulho que nos faz sentir brasileiros.

Nesse sentido, cabe ainda buscar na história da colonização do Brasil fatos que estejam além do que a memória nacional tenta encrustar nas mentes dos brasileiros, uma

\footnotetext{
${ }^{5}$ Oxumaré é o Orixá que rege sobre a sexualidade e seu campo preferencial de atuação é o da renovação dos seres, em todo os aspectos, e em todos os sentidos da vida de um ser. É a força que põe a vida em movimento, cuja representação é uma serpente que morde a própria cauda. A conotação "serpente" não se refere ao réptil, mas simboliza as qualidades afins com os campos vibratórios dos orixás. SARACENI, Rubens. Espiritualidade e sociedade. Disponível em: <http://www.espiritualidades.com.br/Artigos/S_autores /SARACENI _Rubens _ tit _ Oxumare.htm>. Acesso em: 02 fev 2020.
} 

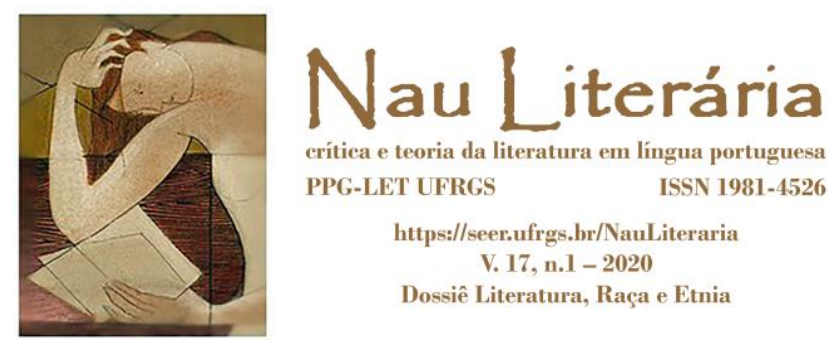

vez que alguns livros sugerem que a escravidão fora algo necessário e que a miscigenação que colore o Brasil foi fruto de relações amigáveis.

No que concerne à questão da escravidão do Brasil, em História Nova do Brasil (1964), Joel Rufino dos Santos apresenta um novo olhar sobre a História do Brasil. O autor enfatiza os numerosos problemas históricos que por vezes foram omitidos às custas da preservação de uma memória nacional ilusória, difundida nos livros didáticos e tomada como verdade inquestionável. No capítulo $O$ sentido da abolição, ele rediscute de maneira pontual a abolição da escravatura e as suas consequências para os que foram postos em liberdade.

Santos (1964) evidencia que a história tem sido falha ao tratar do contingente negro que forma o Brasil e que os livros didáticos têm se limitado apenas a pontuar o trabalho escravo, a questão da lei Áurea e a Campanha Abolicionista, que conferiram à abolição um sentido heroico na figura de alguns e omitem a miséria e a servidão, originária da atual situação do homem pobre brasileiro.

Para o autor, a abolição da escravatura foi, grosso modo, a efetivação da miséria da população negra que ia sendo jogada para fora de seus cativeiros sem indenização, sem terras e sem condições para prosseguir a vida. "A libertação, nesses casos, era uma solução para o senhor e não acarretava sensíveis melhoras na situação do escravo." (SANTOS, 1964, p. 16). Mais e mais pessoas eram jogadas à ociosidade, à libertinagem, à prostituição ou para esmolar nas ruas. Era o retrato de uma estrutura de trabalho falida, que se baseava em grande parte na produção das lavouras cafeeiras, que tinha na mão de obra escrava a produção da maior parte do que consumia e importava. Isso gerou novas condições de trabalho e subsistência como a regressão feudal, na qual se arrendavam pequenas porções de terras aos libertos, braços úteis, explorados ao máximo pelos donos das terras. Eles passavam da condição de escravos para servos, o que gerou por sua vez "a grande e heterogênea classe dos homens livres e indigentes que formavam a pobreza." (SANTOS, 1964, p. 16). 

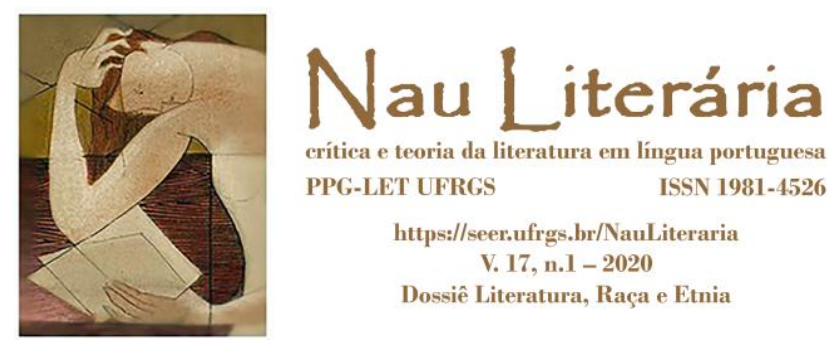

Essas novas condições de trabalho não se limitavam apenas às atividades do campo; nas atividades urbanas, industriais, comerciais ou financeiras das cidades não havia lugar para os escravos. Dispensavam-se os escravos, pois não se podia assalariálos nem os manter, e contratavam-se os imigrantes com baixos salários (SANTOS, 1964, p. 26-27).

Joel Rufino dos Santos menciona que a abolição promoveu a cisão entre os homens que conduziam a política e o governo brasileiro no século XIX. E dessa cisão surgiram os que defendiam a manutenção da escravatura para que não se instaurasse uma espécie de caos sobre a nação, pois perderiam a base da produção econômica e que eram considerados os de direita, e os esquerdistas, aqueles que encabeçavam as campanhas abolicionistas (SANTOS, 1964, p. 27-28).

A Direita, representante do governo, por vezes utilizou-se da promulgação de leis que supostamente beneficiariam os escravos, mas na verdade não passavam de meios de desviar o foco e retardar a chegada da abolição, como por exemplo, a Lei do Ventre Livre, promulgada em 1874, que, em vez de promover a liberdade dos nascituros das escravas, era um meio de institucionalizar a servidão. E mais tarde, em 1885, aprovou-se a Lei dos Sexagenários, divulgada como uma concessão generosa, mas que se tratava de uma maneira criminosa da direita escravocrata para livrar-se das responsabilidades para com os que haviam sido explorados à exaustão e que agora, sem energia e saúde, seriam abandonados à própria sorte (SANTOS, 1964, p. 34-41).

Alguns anos depois, veio o golpe de mestre da direita, e uma parte da história ficou registrada como um ato heroico, a assinatura da Lei Áurea, em 13 de maio de 1888, pela princesa Isabel, que deu a ela o status de heroína, por ter posto fim ao sofrimento da escravidão. Entretanto, a história omite os fatos desencadeados após esse suposto feito heroico, escondendo, portanto, que a abolição foi uma frustração, pois cerca de 700.000 pessoas foram empurradas para uma nova condição de escravidão, aos quais se uniram milhares de servos brancos. Todos foram jogados à servidão eterna e 


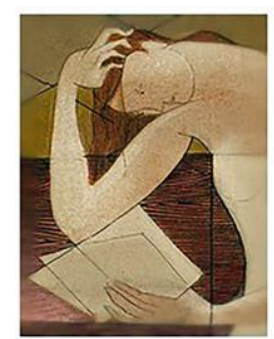

ao monopólio do capitalismo que institucionaliza as diferenças de classes, a miséria e a pobreza (SANTOS, 1964, 44-45).

Para compactuar com a ideia de heroísmo e compaixão do governo para com a população negra escravizada, houve ainda quem tentasse apagar os rastros do que foi a escravidão e suprimir a memória nacional para que não houvesse provas sobre esse crime devastador. Nesse contexto, o sociólogo Octávio Ianni, em sua obra Raças e Classes Socias no Brasil (2004), destaca que, após a Abolição da escravatura, o Ministro da Fazenda, Rui Barbosa, por meio da circular no 29, datada de 13 de maio de 1891, mandou atear fogo a toda documentação referente à escravidão no Brasil (CAVALCANTE, 2017, p. 32). Sobre esta atitude Ianni (2004, p.112) destaca que:

Tratava-se de apagar da memória histórica das gentes a funesta instituição. Era um modo de tornar ainda mais nobre o gesto da abolição e estabelecer a fraternidade, solidariedade e comunhão dos brasileiros. Tentava-se conferir cidadania aos exescravos, negros e mulatos. Para isso, pois, havia que se queimar papéis, livros e documentos relativos ao elemento servil, matrícula de escravos, ingênuos, filhos livres[...]. A consciência liberal dos donos do poder encontrava uma solução simples, sublime como o gesto da abolição: queimam-se os documentos para abolir os fatos.

Criava-se, assim, uma falsa fraternidade entre a população e propagava-se a imagem de um Brasil utópico, no qual não haveria uma divisão de classes tão acentuada e que manteria uma comunhão entre todas as raças. Entretanto, retomando o que fora exposto por Aníbal Quijano (2000), a predominante maioria da raça vigente no Brasil, "a branca", a elite que mantinha grandes posses e os mais altos postos sociais, não admitia ver sua suposta identidade de brasileiros atrelada à figura e aos costumes da população negra, e isso originou fortes reações racistas que não admitiam que os negros participassem ou tivessem direitos na falsa democracia racial brasileira.

Sendo assim, foram ainda criadas ao longo dos anos, no período após a abolição, leis que pretendiam manter a igualdade e a posse dos direitos a todo cidadão brasileiro. A seguir, daremos destaque à Constituição Brasileira, com ênfase no que concerne à igualdade de todos perante a lei, sem distinções:

Constituição de 1891 (artigo 72, parágrafo $2^{\circ}$ ): 


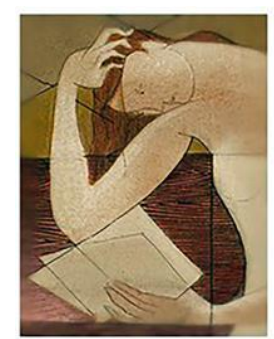

Todos são iguais perante a lei. A República não admite privilégios de nascimento, desconhece foros de nobreza e extingue as ordens honoríficas existentes e todas as suas prerrogativas e regalias, bem como os títulos nobiliárquicos e de conselho.

Constituição de 1934 (artigo 113, parágrafo $1^{\circ}$ ):

Todos são iguais perante a lei. Não haverá privilégios, nem distinções, por motivo, de nascimento, sexo, raça, profissões ou do país, classe social, riqueza, crença religiosas ou idéias políticas.

\section{Emenda Constitucional n.1, de 1969 (artigo 153, parágrafo $1^{\circ}$ ):}

Todos são iguais perante a lei, sem distinção de sexo, raça, trabalho, credo, religiosos e convicções políticas. Será punido pela lei o preconceito de raça.

\section{Constituição Federal de 1988:}

Artigo $5^{\circ}$. Todos são iguais perante a lei, sem distinção de qualquer natureza, garantindo-se aos brasileiros e aos estrangeiros residentes no País a inviolabilidade do direito à vida, à liberdade, à igualdade, à segurança e à propriedade, nos termos seguintes. (BARRETO ${ }^{6}, 2010$, s.p).

Entretanto, mesmo que as autoridades tenham criado leis que visassem a propagar a igualdade entre as raças e direitos comuns a todos, isso não foi o suficiente para privar a população negra que, mesmo após liberta da escravidão, herdou as consequências do racismo que persegue, ofende, oprime e exclui os negros dos seus direitos. Em consonância, Silva e Fernandes (2005, p. 30) esclarecem que "as diferenças culturais e físicas foram usadas como lógica da dominação criada ao longo de quase quatro séculos. Como resultado disso, tivemos uma convivência sob igualdade jurídica e desigualdade social".

Criou-se uma falsa democratização racial que tentou propagar a existência de uma convivência harmoniosa entre os indivíduos e manipular os efeitos causados pelo racismo. Nesse contexto, o antropólogo e professor Kabengele Munanga, em Uma abordagem conceitual das noções de raça, racismo, identidade e etnia (2006), faz a seguinte observação:

O mito da democracia racial, baseado na dupla mestiçagem biológica e cultural entre as três raças originárias, tem uma penetração muito profunda na sociedade brasileira: exalta a idéia de convivência harmoniosa entre os indivíduos de todas as camadas

\footnotetext{
${ }^{6}$ Para mais informações v. BARRETO, Ana Cristina Teixeira. Carta 1988 é um marco contra a discriminação. Disponível em: <https://www.conjur.com.br/2010-nov-05/constituicao-1988-marcodiscriminacao-familia-contemporanea>. Acesso em: 2 jan 2020.
} 


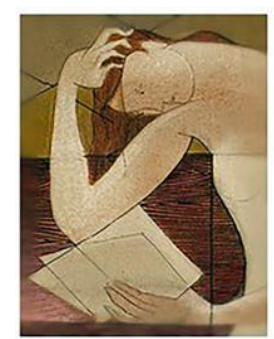

sociais e grupos étnicos, permitindo às elites dominantes dissimular as desigualdades e impedindo os membros das comunidades não-brancas de terem consciência dos sutis mecanismos de exclusão da qual são vítimas na sociedade (MUNANGA, 2006, p. 89)

Esse mito da democracia racial disfarçou, sobretudo, o preconceito racial que se mantém arraigado, pois foi criado e é recriado no interior das classes sociais e é ele o responsável por fomentar as desigualdades sociais (IANNI, 2004 apud CAVALCANTE, 2017, p. 92).

Inebriadas pela falsa democracia racial e ludibriadas pelos sutis mecanismos de exclusão disseminados pelas elites dominantes, as comunidades afrodescendentes passaram a se enxergar pelas lentes etnocêntricas das elites e seus ideais de branqueamento, fazendo com que muitas vezes o indivíduo negro negasse a própria identidade racial, cedendo aos vários estereótipos, apagando as memórias da escravidão que vitimou seus antepassados, exaltando a memória do opressor e buscando o encaixe nos padrões sociais como forma de aceitação e pertença à identidade nacional. Nesse sentido, recorremos ao poema “...E pensar...", com o qual ilustraremos esses apontamentos:

\section{...E PENSAR...}

E pensar que tínhamos vergonha de ser negros, e densos pesadelos sob a pele!...(...)

E pensar que a escravidão subjugava com a sombra de sua garrasgando a cara do tempo dando cartas de alforria registradas no cartório internacional do racismo!...

E pensar que ríamos até quando chamados de nego neguinho negão do jeito folclorizado de preconceito enraizado em latrinas sentimentais!... e que nós mesmos repetíamos descrenças engulidas à força de sutilezas!...

E pensar que acreditávamos na cultura o opressor como a suprema glória em nosso coração ser ver o chicote das leis e trapaças e ódios de prontidão!... (...) 


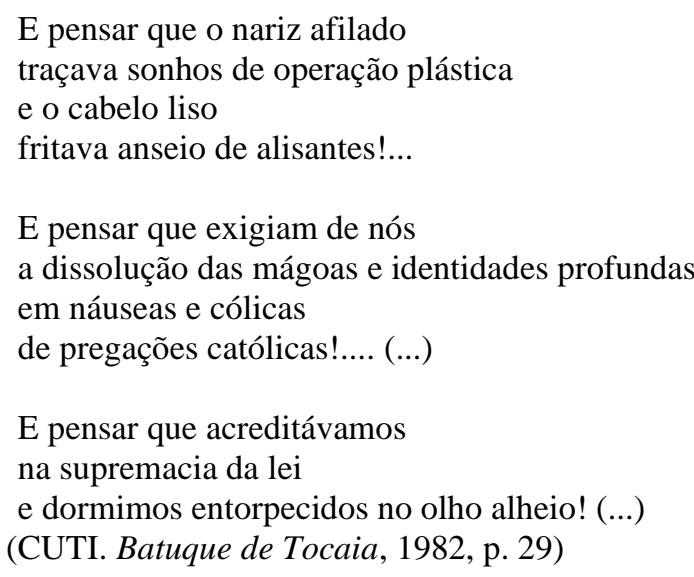

No poema, o eu lírico evoca a coletividade e personifica uma voz que fala do quanto a escravidão deixou pesadas marcas na identidade afrobrasileira. Como em um convite à reflexão, o eu lírico convoca seus irmãos a ver o quanto foram envergonhados ao serem destituídos de suas identidades e obrigados a assumir novas identidades subalternas, que nasciam pela imposição religiosa que mudava seus nomes e lhes reduzia à condição de cativos.

E quando da falsa libertação por intermédio das cartas de alforria ou pelas leis que mais condenavam às novas formas de escravidão do que lhes faziam justiça, restoulhes ainda o preconceito enraizado, que gerou estereótipos e que lhes fez aceitar apelidos pejorativos como "nego neguinho negão" como uma maneira carinhosa de ser aceito. Este preconceito infundiu-lhes o desejo de serem aceitos, mesmo que isso lhes custasse renegar suas raízes e diferenças fenotípicas em busca de um padrão que poderia, ilusoriamente, ser alcançado por químicas de alisamento ou cirurgias plásticas.

O eu lírico convoca ainda os seus à reflexão de como a história foi capaz de propagar a cultura do opressor que perseguia, prendia, matava e lucrava à custa de vidas humanas tratadas como objetos, como uma "glória eterna" que se expandiu e, ainda hoje, obriga o afrobrasileiro a se amar com reticências e viver sob o julgo do racismo que tenta por vezes diminuir e anular os preconceitos que ainda torturam, exploram e anulam vidas à custa da ilusão de uma falsa superioridade. 

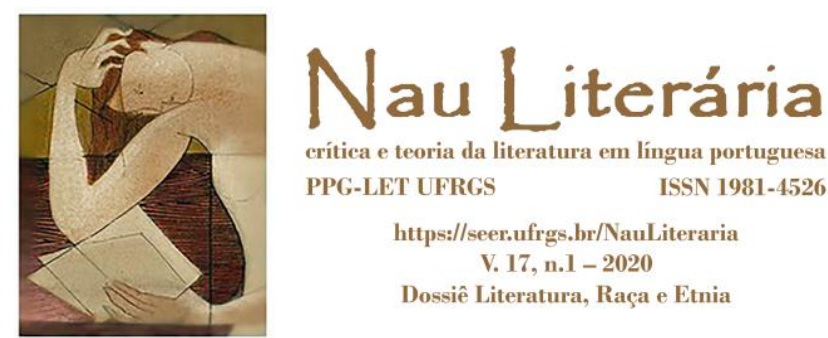

Diante do exposto, podemos observar o quanto a colonização e a escravidão foram pontos cruciais na constituição do Brasil, e não podemos negar aos afrodescentes seu papel de destaque nessa história, ao passo que devemos assumir o compromisso de refletir detidamente sobre os fatos e não apenas aceitar os discursos históricos que foram propagados como forma de ilustrar uma nação constituída de maneira justa e complacente, mas que na prática esconde-se por trás do mito da democracia racial para perpetuar, ainda nos dias atuais, as mais cruéis formas de preconceito.

\section{4 "A nossa própria imagem no espelho deles": poesia negra trilhando caminho na literatura branca}

A constituição do Brasil enquanto Estado-nação e o estabelecimento de leis que promulgavam a igualdade entre os brasileiros davam ao Brasil um status de nação imaginada, que, segundo Benedict Anderson, em Comunidades imaginadas: reflexões sobre a origem e a difusão do nacionalismo (2008), pode ser conceituada como "uma comunidade política imaginada" na qual "todos tenham em mente a imagem viva da comunhão entre eles.” (ANDERSON, 2008, p. 32).

Convém destacar que a esse conceito de nação coube a designação de uma identidade nacional, homogênea, que pretendia abarcar essa comunhão. Desse modo, criou-se uma identidade nacional, que negava a descendência do Outro, o indígena, o negro, o mestiço e pautava-se em ideais eurocêntricos.

Coube ainda à elite letrada institucionalizar essa identidade, ou seja, "a literatura se institucionalizou como instrumento pedagógico (...) para sustentar a coerência e a unidade política da concepção romântica da nação como ‘o todos em um'.” (SCHMIDT, 2000, p. 84).

Para Schmidt (2000, p. 87):

Os esforços da elite letrada brasileira em construir uma narrativa nacional no século XIX e a concomitante psicologização da política, com a institucionalização de uma memória coletiva, de caráter uniformizador, resultante da violência perpetrada em nome de uma identidade que se projeta, do ponto de vista de classe, raça e gênero como hegemônica, pautou-se no nacionalismo romântico (...). 


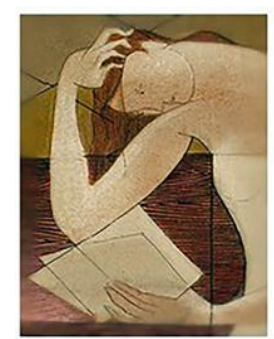

Nessa visão hegemônica do nacionalismo romântico, a literatura propagava "o modelo cultural dominante da missão civilizatória, dentro do paradigma etnocentrista do colonizador" (SCHMIDT, 2000, p.86), o que fez com que algumas obras tidas como fundadoras do nacionalismo brasileiro, como o romance Iracema, de José de Alencar (1865), expusessem a origem da nova raça, fruto da miscigenação, como uma união harmoniosa entre o colonizador (o branco) e o selvagem (o índio) (SCHMIDT, 2000, p. 86).

Cabe ainda expor que o ideal etnocêntrico da literatura brasileira foi propagado no que concerne à exposição da figura do negro. Sendo assim, "durante muito tempo, no Brasil, as memórias e as histórias dos afrobrasileiros limitaram-se à reiteração do estigma da escravidão, à representação do negro como escravo e vítima submissa dos castigos e infortúnios sofridos na sociedade escravista." (ALMEIDA7 , 2016, p. 436). Como exemplo, temos o poema O Navio Negreiro (1870), do escritor Castro Alves, proclamado pelo cânone com a alcunha de "poeta dos escravos".

\section{O NAVIO NEGREIRO}

São os filhos do deserto, Onde a terra esposa a luz. Onde vive em campo aberto A tribo dos homens nus... São os guerreiros ousados Que com os tigres mosqueados Combatem na solidão. Ontem simples, fortes, bravos. Hoje míseros escravos, Sem luz, sem ar, sem razão. . .

São mulheres desgraçadas, Como Agar o foi também. Que sedentas, alquebradas, De longe... bem longe vêm... Trazendo com tíbios passos, Filhos e algemas nos braços,

\footnotetext{
${ }^{7}$ ALMEIDA, Jaqueline de. Negro e pronto: a representação do negro na poética de Cuti, 2016, p. 431441. Jan. de 2020.
} 


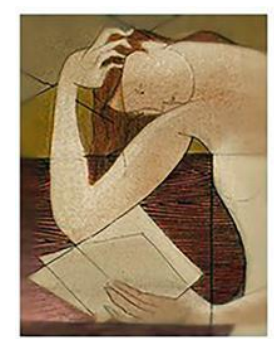

N'alma - lágrimas e fel...

Como Agar sofrendo tanto,

Que nem o leite de pranto

Têm que dar para Ismael.

(ALVES, Castro. O Navio Negreiro, 2000, s. p)

Em outras instâncias, o negro era representado de forma rude e subalterna, ou seja, era exposto de forma bastarda e caracterizado como uma figura exótica no que se referia ao seu porte físico. Verifica-se ainda o enaltecimento sexual da mulher negra, na figura da mulata sedutora (SILVA, 2016, p. 50), conforme podemos observar no apanhado teórico de Assis Duarte (2007):

[...] os estereótipos do escravo vingativo e assassino, do feiticeiro deformado física e moralmente, ou da mucama pervertida que destrói a família do senhor, estão presentes em "Vítimas e algozes", de Joaquim Manoel de Macedo; já a mulata assanhada, que seduz e leva o português à perdição, destaca-se nas páginas de "O cortiço", de Aluízio Azevedo; e o negro de alma branca, reduzido a cão fiel ao senhor, ajuda a compor a figura do preto Domingos, personagem de José do Patrocínio em "Mota Coqueiro". Apesar de condenarem explicitamente a escravidão e de se envolverem na campanha abolicionista, que, inclusive, tem em Patrocínio um de seus líderes, tais autores deixam aflorar em seus textos as marcas discursivas oriundas do pensamento racial hegemônico [...] (DUARTE, 2007, p. 251-252).

Nesse período a literatura como símbolo da Nação Brasileira se constituiu "como signo de valor e repositório de identidade de uma cultura que buscava se legitimar como tal, através de uma imagem de autonomia, coesão e unidade, nasciam as determinações que produziriam o corpus oficial da literatura brasileira, ou seja, o cânone literário." (SCHMIDT, 2000, p. 89).

Esse cânone era, por sua vez, a representação da tradição, e tudo que não se enquadrava nesses padrões era considerado como não-literário, portanto, ficava à margem do que era publicado e difundido como pertencente a nossa literatura.

Desse modo, a literatura era efetivada como um silenciamento dos negros, ou ainda como uma forma de "apagar os vínculos étnicos e os traços físicos, apagar a cor em situações determinadas [...] seu grupo étnico é esquecido para registrar apenas a excepcionalidade da situação" (SOUZA, 2005, p. 36). Essa literatura servia apenas ao propósito de efetivar o preconceito e propagar o racismo. 


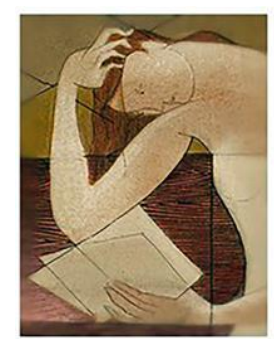

A partir do século XX vieram à tona textos que buscavam reclamar ao negro seu lugar de destaque dentro da história e da literatura brasileira, e nesse intuito surgiram textos literários pertencentes à literatura afrobrasileira, definida por Zilá Bernd (1988) como uma literatura

[...] feita por negros ou descendentes assumidos de negros [...] reveladora de visões de mundo, de ideologias e de modos de realizações que, por força de condições atávicas, sociais e históricas, se caracterizam por uma certa especificidade, ligada a um intuito definido de singularidade cultural (BERND, 1988, p. 21).

Uma forma de expressão literária “onde um 'eu' enunciador assume uma identidade negra" (BERND, 1998, p. 91). Esse eu anunciador assume-se com sujeito do discurso e assume a sua consciência em fazer parte da nação brasileira, bem como reivindica suas raízes. "Assim há sempre um eu enunciador que fala em nome de um nós da comunidade, dirigindo-se a um tu, ouvinte/leitor que deve ser sensibilizado pela palavra poética e motivado a aderir à mesma luta.” (BERND, 1998, p. 98).

Ainda de acordo com Bernd (1992, p. 267-276), o surgimento dessa literatura serviu como

[...] uma espécie de divisor de águas entre um discurso sobre o negro, que sempre existiu na literatura brasileira, e um discurso do negro que corresponde ao desejo de renovar a representação convencional constituída ao longo dos séculos, quase sempre carregada de preconceitos e de estereótipos.

Cabe ainda mencionar que, dentro dessa vertente da literatura, o poeta citado neste artigo, Cuti, teve papel de destaque, pois, conforme Zilá Bernd (1988), o seu fazer poético configurou-se como um "demarcador de fronteiras" entre a figura estereotipada do negro e "o surgimento de um sujeito de enunciação no discurso poético, revelador de um processo de conscientização de ser negro entre brancos" (BERND, 1988, p. 48).

Nesse contexto, passamos a seguir, à análise de um dos poemas de Cuti que ilustra estas discussões:

\section{CHEIRO}

Vem ver

Vem sentir

O cheiro de suor da nossa voz escrita 

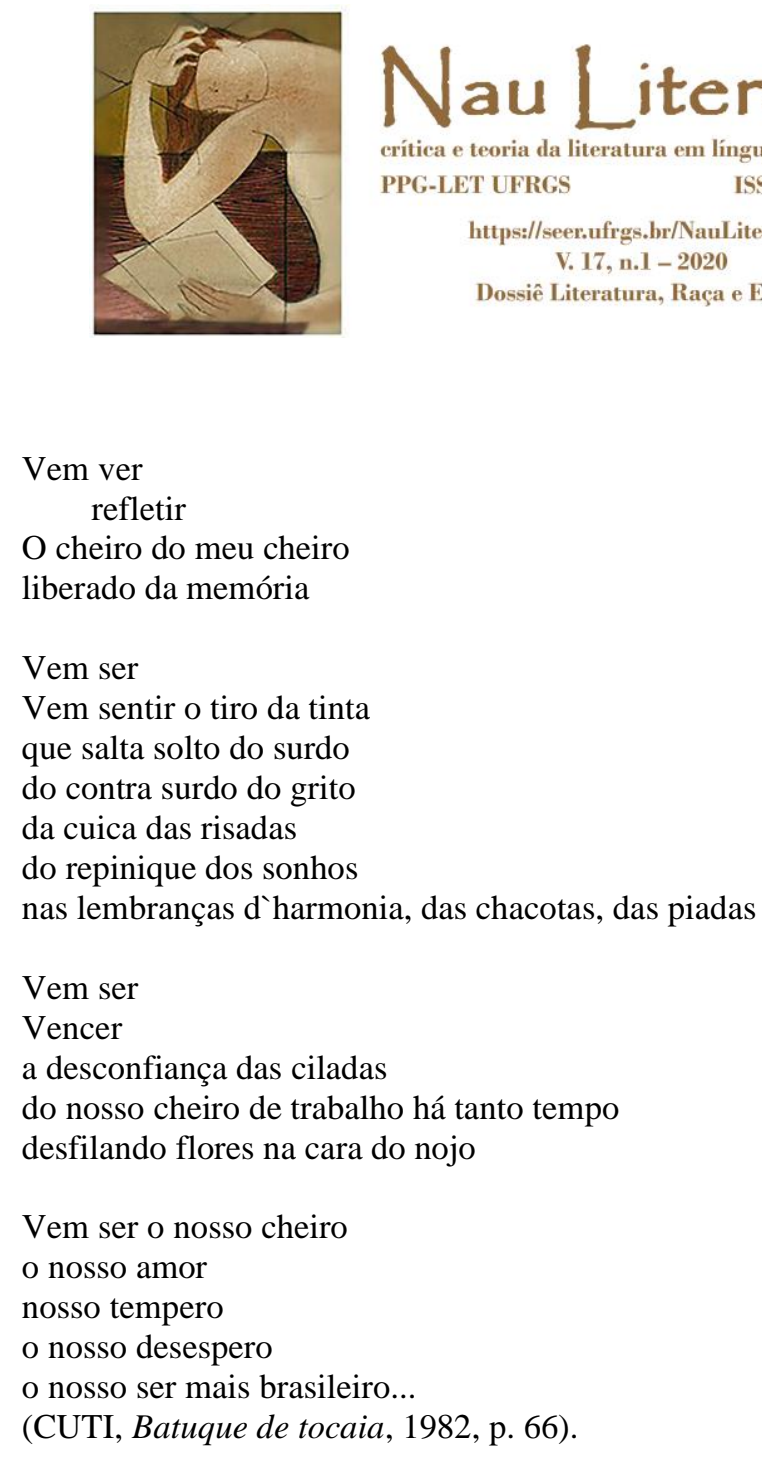

No poema em tela, há a presença de um eu lírico que incorpora a voz de seus iguais ao fazer uso do pronome possessivo "nosso". Cabe aqui remeter o termo "cheiro" ao significado de essência, que nos leva a um movimento que transpõe a simples barreira do existir sobre a ótica que nos define, pois o eu lírico inicia seus versos, convocando os brancos a ver o real sentido da história dos negros, sentir a essência do suor derramado como parte da escrita da história da nação brasileira. Ao mesmo tempo, há uma convocação aos seus irmãos negros a "ser", no sentido de existir, de deixar falar suas memórias, sonhos enterrados, gritos silenciados e pôr um fim no preconceito "das chacotas, das piadas" dos quais foram vítimas ao longo dos séculos.

Há ainda a convocação para "vencer a desconfiança das ciladas" armadas por aqueles que desprezam e ignoram o árduo trabalho do negro na construção da nação, aqueles cuja arrogância não permite que se sintam negros, porque se julgam superiores.

Nos versos finais, o eu lírico convoca a todos negros e brancos a se sentirem brasileiros, convoca-os à autoaceitação, a apagarem as diferenças, deixar transparecer 


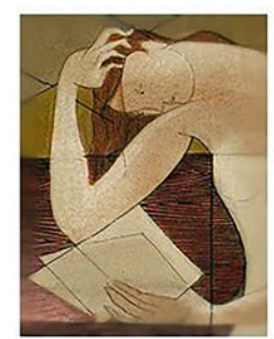

uma identidade múltipla que abarca "cheiro, tempero, amor, desespero" no cerne do que significa "ser brasileiro".

\section{Palavra com palavra: memória, identidade e resistência na poesia de Cuti}

A cada indivíduo é imposto ao nascer o pertencimento a um determinado contexto, seja ele familiar, social ou nacional. Ao tornar-se consciente de si, esse sujeito manifesta voluntariamente um sentimento de pertencimento, o qual ele construiu e modelou no seu convívio diário com os vários segmentos nos quais esteve inserido. A esse sentimento de pertença pode ser atribuído o nome de identidade. Segundo Hall (2002, p. 11), cada indivíduo constitui sua identidade a partir da interação do Eu com a sociedade, num processo contínuo de diálogo com os mundos culturais e as identidades que esses mundos proporcionam. Ou seja, à medida que vivencia novas realidades e com elas suas culturas e identidades, o sujeito vai construindo e reconstruindo a sua própria existência, o que evidencia o caráter flexível e cambiante de constituição de uma identidade, em contraste com o caráter estanque de unicidade e homogeneidade que por vezes lhe é atribuído.

Ainda de acordo com Hall (2009, p.107), "as identidades são construções, isto é, são criadas e recriadas no decorrer do tempo e respondem às necessidades dos indivíduos que as constroem. Por isso são fundadas na fantasia, na projeção e na idealização". Enquanto construções passíveis de criação e recriação que suprem nos indivíduos suas fantasias, projeções e idealizações, as identidades também refletem as memórias que as constroem, pois os indivíduos são os reflexos das histórias que viveram e vivem, e que povoam sua essência. Neste ponto, cabe-nos buscar elucidar a estreita relação entre memória e identidade, com base no que diz Michael Pollak (1992, p. 204), em Memória e identidade social:

a memória é um elemento constituinte do sentimento de identidade, tanto individual como coletiva, na medida em que ela é também um fator extremamente importante do sentimento de continuidade de coerência de uma pessoa de um grupo em sua reconstrução de si. 

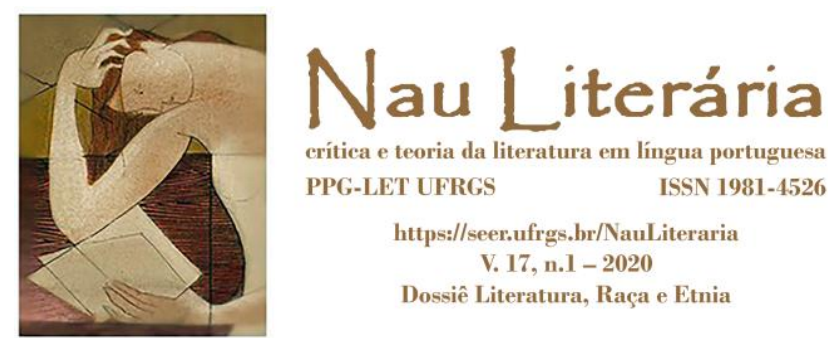

Destarte, cabe destacar que, à medida que experienciamos o convívio com os demais, vamos construindo memórias e vínculos de pertença, assim é possível ao indivíduo declarar-se como parte de um todo.

Retomando Hall (2009), ao mencionar que as identidades podem ser fundadas na projeção, na fantasia ou idealização, levantamos a questão de como a identidade entendida como "brasileira" foi, por muito tempo, forjada e modelada no que a memória nacional pretendia expor como única e aceitável.

Conforme citado anteriormente, no processo de constituição do Brasil enquanto Estado-nação, a identidade nacional foi construída com base em padrões eurocêntricos que rechaçavam qualquer parentesco com as identidades e culturas tidas como subalternas, porque eram advindas de índios, negros ou mestiços.

Quando algum negro conseguia ter acesso à sociedade etnocêntrica, por vezes era mantido à margem e "pagava o preço do massacre mais ou menos dramático de sua identidade", pois era "afastado de seus valores originais, representados fundamentalmente por sua herança religiosa" e tomava "o branco como modelo de identificação, como única possibilidade de tornar-se gente." (SOUZA, 1983, p. 18).

A memória nacional propagou por séculos a ideia de uma nação ideal, que, embora tivesse sido construída com base no massacre e na barbárie, expandiu-se como una, igualitária e sem preconceitos de raça. E de posse de uma elite letrada, buscou suporte no cânone literário de padrão estético exclusivamente masculino, branco e ocidental para difundir e consolidar a memória nacional brasileira (CAVALCANTE, 2017, p. 90).

Para galgar seu espaço nessa memória literária e pôr em evidência a sua autoaceitação enquanto negro, foi necessário um movimento de conscientização que buscou dar voz à figura do negro e levá-lo à construção da sua identidade enquanto brasileiro. A esse propósito serviu a literatura afrobrasileira cujo “"eu’ enunciador adquiriu uma identidade negra, no anseio de reconquistar as raízes culturais 

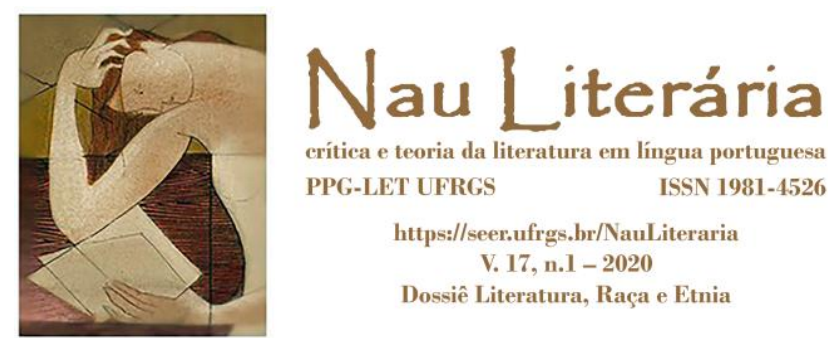

afrobrasileiras e uma literatura de protesto contra a discriminação da qual é vítima o povo negro brasileiro." (SILVA, 2016, p. 41).

O que emergia com esse novo campo literário era o fim da branquitude do negro, pregava-se o fim da sujeição à imposição alienante de tentar enquadrar-se num padrão que exigia sacrifícios como os de negar sua cultura e suas raízes, bem como pregava o anulamento de uma identidade em função de outra. O negro passava a se assumir e se aceitar como sujeito social e lutar pelo seu direito em participar da sociedade. Por esse viés de reinvindicação e aceitação, o afrodescendente pode por sua vez repensar a sua

identidade como um processo ligado à ideia de alteridade, no processo de construção e desconstrução identitária na relação com a diferença. Esta consciência da diferença para o negro brasileiro é o elemento sobre o qual se funda um projeto de superação da sua marginalidade histórica (BERND, 1987, apud Silva, 2016, p. 41).

Um dos campos de destaque desta nova vertente literária foi o da poesia, uma vez que este gênero se destaca pelo alto grau de subjetividade que carrega em seu cerne, e que, por sua vez, permite ao seu autor esboçar sentimentos, inquietações e desejos, bem como deixar transparecer seu pertencimento identitário.

A poesia negra ou afrobrasileira em seu plano estético e literário serviu bem a este propósito, uma vez que permitiu ao negro "inscrever, nas malhas do tecido poético, o processo de transformação ideológica de sua consciência individual que atinge sua autonomia ao libertar-se do poder do discurso mistificador da dominação." (BERND, 1988 apud CAVALCANTE, 2017, p. 94).

Por intermédio da poesia afrobrasileira, o afrodescendente conquistou seu direito à voz e pode fazer uso de uma das ferramentas mais poderosas da elocução - a palavra. Nesse sentido, recorremos à análise do poema Palavra, buscando destacar o fazer poético de Cuti no que concerne à afirmação da identidade afrobrasileria dentro da memória nacional brasileira.

\section{PALAVRA}

Palavra que sai espremida da violência e do sarcasmo dos bêbados felizes deitados na rede da ilusão dum Brasil branco 


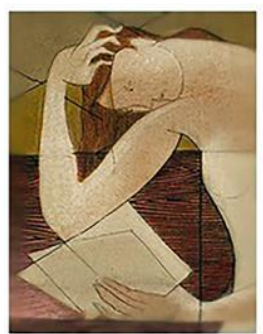

arrotando a vergonha-sobremesa do nosso olho hesitante de olhar para trás

dos partidários de Rui na queima da "Mancha Negra" do esquecimento das feridas que escorrem pus na carne de milhões de brasileiros nós

que sai do cheiro podre das favelas onde a cor das pessoas é seta é meta direta na mentalidade escravagista em franco processo disfarçado

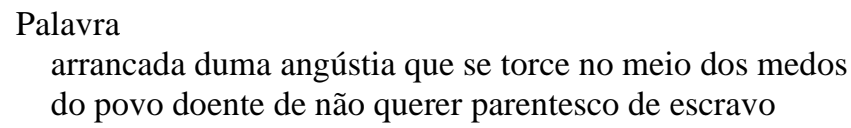

Palavra com palavra que se embola toda em bolhas que fervilha pela estrada dessa história de nós povo aqui trazido aqui sugado aqui bagaço

Palavra cobrança na porta cuspido

da consciência nacional sinal do sentimento nosso nessa língua estrangeira por enquanto.

(CUTI, Batuque de tocaia, 1982, p. 54-55).

No poema em tela, o eu lírico começa por destacar a violência que o afrobrasileiro teve que enfrentar para se manter vivo na memória nacional, que por vezes difundiu a ideia de um "Brasil branco". Os versos iniciais revelam também que, mesmo após a abolição da escravidão, ainda há um povo hesitante "em olhar para trás" com medo de desfazer a branquitude imposta pelo preconceito racial. Na sequência, o eu enunciador faz menção ao ato covarde do ministro da fazenda Rui Barbosa que, com apoio partidário e legislativo, em 1981, pouco tempo após a abolição da escravidão no Brasil, mandou atear fogo à documentação referente à escravidão no Brasil numa tentativa inescrupulosa de apagar o que para as autoridades e a elite era apenas uma "Mancha Negra" na história da memória nacional brasileira, mas que é a história de 

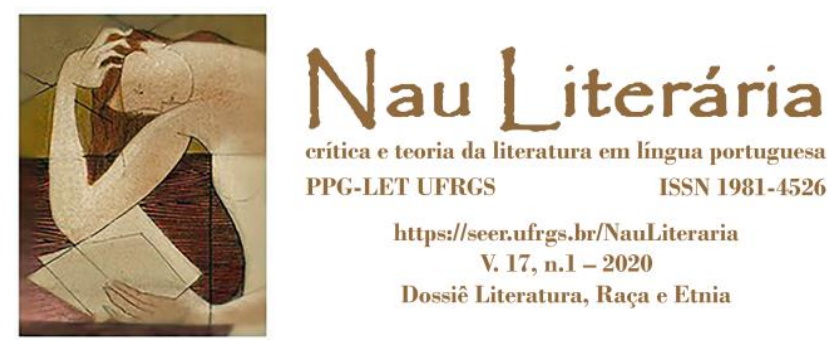

milhões de brasileiros, eles e agora "nós", os herdeiros que compomos uma parte importante nesta história.

A palavra citada nos versos do poema é a voz negada aos milhares de negros que após a abolição foram despejados à margem da sociedade e que ainda hoje tem seu direito à fala negado por sua cor, por morarem em favelas ou por não se encaixarem no padrão da "mentalidade escravagista" que ainda habita no inconsciente da sociedade racista.

Essa palavra foi negada aos que foram covardemente arrancados de suas terras e trazidos ao Brasil para serem escravizados, sugados, esmagados e cuspidos em forma de bagaço por um sistema opressor construído na ideia de superioridade racial.

O poema é a palavra ontem silenciada e que hoje é a "cobrança na porta da consciência nacional", é a voz do sentimento de milhares de brasileiros que foram marginalizados e que hoje lutam para assumir a sua identidade, para manter viva a memória dos seus nessa terra onde alguns julgaram, e que por vezes ainda julgam, o diferente como o alheio, o estrangeiro, o que não pode pertencer à identidade brasileira.

\section{Considerações finais}

Neste artigo, pretendemos elucidar questões referentes à memória, identidade e autoaceitação do afrodescentente na poesia de Luiz Silva (CUTI), uma vez que esse autor foi e continua sendo uma das grandes figuras da militância literária no que concerne à afirmação da identidade afrobrasileira dentro da literatura brasileira.

Durante as discussões, observamos que o que perdurou ao longo dos anos na literatura brasileira foi a visão hegemônica e romântica do cânone literário que por vezes excluiu e silenciou outras vozes que se distanciavam do padrão eurocêntrico de construção da memória nacional.

Por anos, a literatura serviu apenas ao propósito de propagar uma identidade nacional, na qual o requisito básico para ser brasileiro ligava-se a questões de descendência nobre associadas à figura do colonizador. Ela se manteve resistente em 

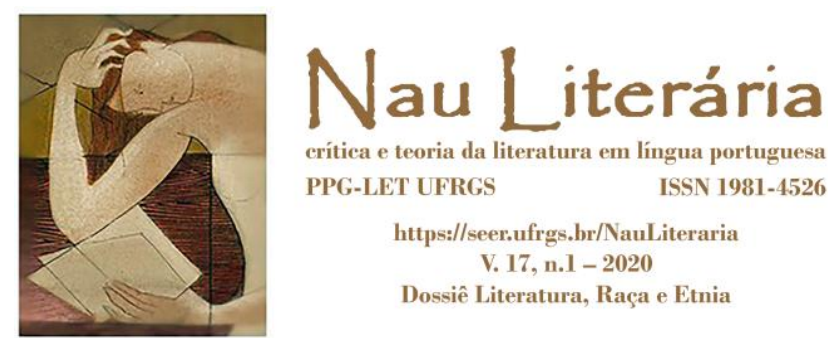

deixar que manchassem a memória nacional com as histórias dos povos escravizados e torturados durante o período da colonização do Brasil.

Entretanto, movidos pelo desejo de descontruir estes padrões etnocêntricos e dar voz aos sujeitos que foram jogados à margem da sociedade, um grupo de autores cumpriu o propósito de imprimir na história da literatura brasileira a figura do negro, não apenas como o escravo, o subalterno ou o sujeito cordialmente usado para a miscigenação, mas como um sujeito altivo, lutador e que contribuiu significativamente na construção do Brasil.

Esse grupo de autores pertence à literatura afrobrasileira, um fazer literário com reflexões sociológicas que reconfiguraram a literatura e a memória nacional brasileira. Cabe destacar que, neste artigo, buscamos reflexões teóricas que confirmaram o quão esta vertente literária contribuiu e ainda contribui com a construção de uma literatura do negro e para o negro, "do negro" porque foi, e ainda é, escrita por autores negros, afrodescendentes que não negam suas origens, e "para o negro" porque se dedicou a anular estereótipos e lutar contra o racismo que vitima e tenta diminuir a figura do negro dentro da nossa sociedade.

Isto posto, concluímos que os versos de Luiz Silva, em destaque nos poemas aqui analisados, são o externar de um eu enunciador que convoca os seus à autoaceitação, ou seja, convoca-os a se admitirem identitariamente como negros e a lutarem pela afirmação dessa identidade tão marginalizada histórica e socialmente. Convoca-os ainda a buscar o seu lugar na história, e não mais admitir que o racismo subjugue sua importância e desmereça a sua contribuição, e tampouco anule as suas lutas ou desmereça a herança cultural que compõe o cenário identitário e cultural brasileiro.

\section{Referências}

ALVES, Castro. Navio Negreiro. Editora Virtual Books. Online M\&M Editores Ltda: 2000. 

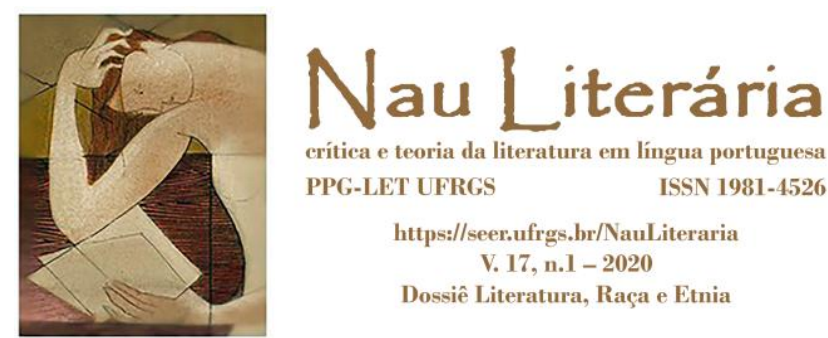

ALMEIDA, Jaqueline de. Negro e pronto: a representação do negro na poética de Cuti, 2016, p. 431-441. Disponível em: < https://www.ufrgs.br/ppgletras/coloquiosularquipelagos /artigos /46_Negroepronto.pdf>. Acesso em: 13 jan 2020.

ANDERSON, Benedict R. Comunidades Imaginadas: reflexões sobre a origem e a difusão do nacionalismo. São Paulo: Companhia das Letras, 2008.

BARRETO, Ana Cristina Teixeira. Carta 1988 é um marco contra a discriminação. Disponível em: < https://www.conjur.com.br/2010-nov-05/constituicao-1988-marcodiscriminacao-familia-contemporanea>. Acesso em: 02 jan 2020.

BERND, Zilá. Negritude e Literatura na América Latina. Porto Alegre: Mercado Aberto, 1987.

BERND, Zilá. Introdução à literatura negra. São Paulo: Brasiliense, 1988.

BERND, Zilá. Poesia negra brasileira. Porto Alegre: AGE, 1992.

BERND, Zilá. Literatura Negra: Racismo e defesa de direitos humanos. Revista do Mestrado em Letras da UFMS. Santa Maria, p. 91 a 102. jan-Jun, 1998.

CAVALCANTE, Francys Carla Arraiz Lindoso. Literatura afro-brasileira: um processo de afirmação identitária e de resistência negra na poesia de Cuti. Opiniães: Revista dos Alunos de Literatura Brasileira, São Paulo, ano 6, n. 10, p. 86-102. 2017.

CUTI. Batuque de tocaia. São Paulo: s. ed, 1982.

CUTI, Luiz Silva. Literatura negro-brasileira. São Paulo: Selo Negro, 2010.

DUARTE, Eduardo de Assis. O Bildungsroman afro-brasileiro de Conceição Evaristo. In: ALEXANDRE, Marcos Antônio (Org.). Representações performáticas brasileiras: teorias, práticas e suas interfaces. Belo Horizonte: Mazza Edições, 2007. p.22-29.

DUARTE, Eduardo de Assis. Literatura afro-brasileira: um conceito em construção. Estudos de Literatura Brasileira Contemporânea, Brasília, n. 31, p. 11-23. jan-jun. 2008.

HALL, Stuart. Da diáspora: identidades e mediações. Organização Liv Sovik. Trad. Adelaide La Guardia Resende [et al.]. Belo Horizonte: Editora UFMG, 2009. 

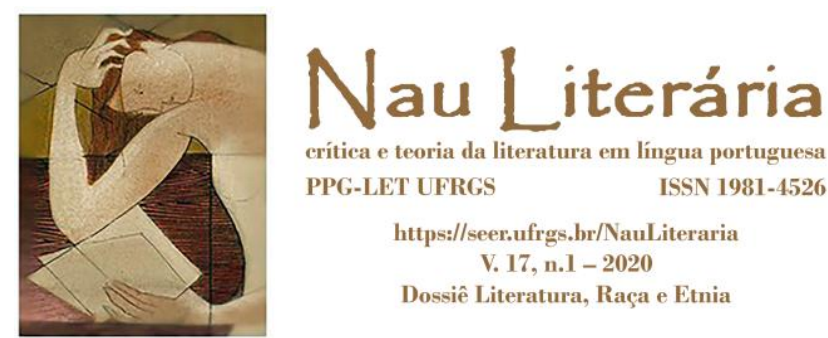

HALL, Stuart. A identidade cultural na pós-modernidade. 7.ed. Rio de Janeiro: DP \&A, 2002.

MUNANGA, K. Algumas consideracões sobre "raça", ação afirmativa e identidade negra no Brasil: fundamentos antropológicos. Revista USP, São Paulo, v. 68, p. 46-57, 2006.

QUIJANO, Aníbal. Colonialidad del poder, eurocentrismo y América Latina. In: LANDER, Edgardo (Org.). La colonialidad del saber: eurocentrismo y ciencias sociales. Perspectivas Latinoamericanas. Buenos Aires: CLACSO, Consejo Latinoamericano de Ciencias Sociales, 2000.

SARACENI, Rubens. Espiritualidade e sociedade. Disponível em: <http://www.espiritualida des. com.br/Artigos/S_autores /SARACENI_Rubens_tit_ Oxumare.htm>. Acesso em: 02 fev 2020.

SANTOS, Joel Rufino dos. História Nova do Brasil. Abolição; República; Florianismo. São Paulo: Brasiliense, 1964.

SILVA, Elen Karla Sousa da. Errância e reescrita da identidade negra em Ponciá Vicêncio, de Conceição Evaristo. 2016. 129 fs. Dissertação (Mestrado em Letras) Universidade Estadual do Rio Grande do Norte, Pau dos Ferros, 2016.

SILVA, Lúcia Helena Oliveira; FERNANDES, Frederico Augusto Garcia Fernandes (orgs.). Caderno Uniafro I, Cultura Afro-Brasilleira, Expressões Religiosas e Questões Escolares. Londrina: Universidade Estadual de Londrina, 2005.

SOUZA, Florentina da Silva. Afrodescendência em Cadernos Negros e Jornal do $M N U$. Belo Horizonte: Autêntica, 2005.

SOUZA, Neusa Santos. Tornar-se Negro. Rio de Janeiro: Graal, 1983.

SCHMIDT, Rita T. Mulheres reescrevendo a nação. In: Revista Estudos Feministas, v.8, n. 1.2000. 